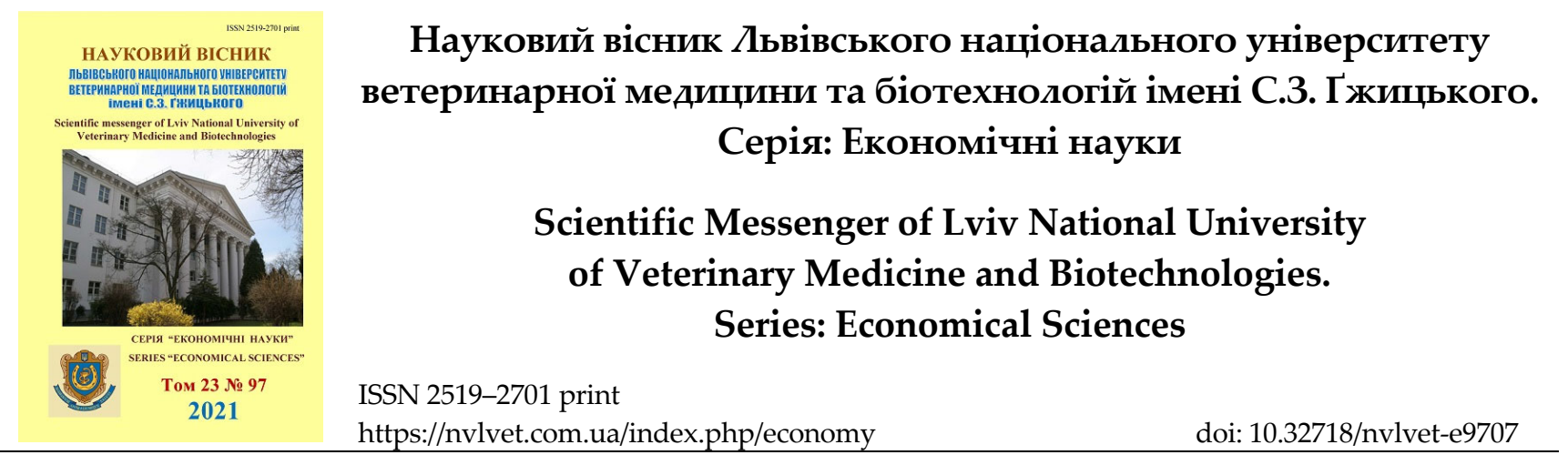

UDC 338.24

\title{
Market adaptation of agricultural enterprises
}

\author{
S. Poperechny, O. Salamin
}

Stepan Gzhytskyi National University of Veterinary Medicine and Biotechnologies Lviv, Lviv, Ukraine

Article info

Received 23.09.2021

Received in revised form 25.10 .2021

Accepted 26.10.2021

Stepan Gzhytskyi National University of Veterinary Medicine and Biotechnologies Lviv,

Pekarska Str., 50, Lviv, 79010, Ukraine.

Tel.: +38-067-253-32-67

E-mail: stepany2008@ukr.net
Poperechny, S., \& Salamin, O. (2021). Market adaptation of agricultural enterprises. Scientific Messenger of Lviv National University of Veterinary Medicine and Biotechnologies. Series: Economical Sciences, 23(97), 36-40. doi: 10.32718/nvlvet-e9707

Problems of adaptation agricultural enterprises to the market environment are analyzed. Adaptation in agriculture is complicated by the long production period and volatility of product prices. Due to the improper formation of infrastructure, the agricultural market does not perform the function of price stabilization. Constant re-profiling of the enterprise is required. This does not contribute to stable functioning. There are not price forecasting services in Ukraine. Financial resources and staffing of even relatively large enterprises are insufficient for such forecasting. In such conditions, especially large-sized enterprises are developing as a priority. Their activities are focused on foreign markets, where prices are more stable. This strengthens the export potential of Ukraine's agriculture and exacerbates rural unemployment and social problems in rural areas. In addition, it is difficult for large enterprises to adapt to market environment. Compared to small enterprises, their re-profiling requires longer time and greater financial resources. In highly competitive markets, the differentiation of consumers by requirements for food products is growing. Manufacturers of undifferentiated mass-produced products using intensive technologies are losing their competitive position. The popularity of small batches of products is growing, which is more acceptable for potential consumers of target market segments. The production and bringing to market of such products requires the coordinated activities of all economic entities united by a common chain of movement of goods. To achieve this, state incentives are needed for the creation and development of cluster-type economic systems, which harmonize the requirements for raw materials and products of its processing, delivery times, prices. Production of craft products can be organized in some agricultural enterprises. The higher cost of such products is offset by higher sales prices. The creation of such systems can be initiated by processing enterprises that invest in the production of raw materials. State support for such structures is more effective than direct state financial support for individual industries.

Key words: market infrastructure, price volatility, adaptation of the enterprise to the market environment, clusters, state support of agriculture.

\section{Ринкова адаптація сільськогосподарських підприємств}

\author{
С. Поперечний, О. Саламін
}

Львівський національний університет ветеринарної медицини та біотехнологій імені С. 3. Гжсицького, м. Львів, Україна

Аналізуються проблеми адаптаиії сільськогосподарських підприємств до ринкового середовища. Показано, ияо така адаптація у сільському господарстві ускладнена тривалим виробничим періодом і волатильністю цін на продукцію. Через неналежну сформованість інфраструктури аграрний ринок не виконує функиії стабілізації иін. Вимагається постійне перепрофілювання підприємства, щзо не сприяє його стабільному функціонуванню. В Украӥні відсутні служби, щуо здійснюють прогнозування цін. Фінансові ресурси і кадрове забезпечення навіть порівняно великих підприємств недостатні для такого прогнозування. В таких умовах пріоритетно розвиваються особливо великі за розмірами підприємства голдингового типу. Їх діяльність спрямовується на зовнішні ринки, де изіни стабільніші. Це забезпечує посилення експортного потенціалу сільського господарства України, а також посилює безробіття у селах та сочіальні проблеми сільських населених пунктів. Крім того великим підприємствам складно адаптуватись до мінливого ринкового середовища. Порівняно з невеликими підприємствами для ӥх перепрофілювання вимагаються триваліші 
терміни та більші фінансові ресурси. На висококонкурентних ринках зростає диференціація споживачів за вимогами до продовольчих товарів. Втрачають конкурентні позищї виробники недиференщійованої продукцї масового виробництва з використанням інтенсивних технологій. Зростає популярність невеликих партій продукиії, яка за ознаками прийнятніша для потенційних споживачів изільових сегментів ринку. Для виробництва $і$ виведення такої продукції на ринок необхідна узгоджена діяльність усіх суб 'єктів господарювання, об'єднаних спільним ланцюгом руху товарної маси. Для досягнення иього необхідне державне стимулювання створення і розвитку економічних систем кластерного типу, у яких узгоджуються вимоги до сировини та продуктів ї̈ переробки, терміни поставок, ціни тощуо. Може організуватись виробництво крафтової продукиії в окремих сільськогосподарських підприємствах. Вища собівартість такої продукиї компенсується вищими цінами ї̈ реалізаціі. Ініціювати створення таких систем можуть переробні підприємства, які інвестують кошти у сферу виробництва сировини. Державна підтримка таких структур ефективніша, ніж пряма державна фінансова підтримка окремих галузей.

Ключові слова: інфраструктура ринку, волатильність иүін, адаптація підприємства до ринкового середовища, кластери, державна підтримка сільського господарства.

\section{Ветуп}

Визначальний вплив на поведінку суб'єктів господарювання в умовах ринкових відносин мають чинники ринкового механізму регулювання економіки. Такий загальноприйнятий, поширений в економічних публікаціях підхід до пояснення мотивів поведінки суб'єктів господарювання і їх адаптації до ринкового середовища поєднується 3 трактуванням автоматичності впливу ринкових важелів на учасників ринкових відносин.

Визначальний вплив на поведінку сільськогосподарських товаровиробників має ціна. Тому на проблеми дослідження цінових тенденцій і відповідні, зумовлені ціною результати господарювання у наукових публікаціях звертається особлива увага (Pauhofova \& Qineti, 2002; Czyzewski \& Majchrzak, 2018; Rembisz \& Waszkowski, 2018). Поширені публікації, у яких аналізуються підходи до прогнозування цін $\mathrm{i}$ визначення їх очікуваного рівня (Shyian et al., 2021). Традиційними, та такими, що не втрачають актуальності $є$ дослідження 3 проблем співвідношення між рівнями цін на сільськогосподарську продукцію і цін на засоби виробництва для сільського господарства. При цьому обгрунтовується, що саме цим співвідношенням визначаються можливості залучення факторів виробництва, оновлення і використання прийнятної технологіï (Rembisz \& Waszkowski, 2018; Czyzewski \& Majchrzak, 2018). Вагомим елементом ринкового механізму регулювання економіки $є$ конкуренція. Через це поширеними $\epsilon$ публікації за результатами дослідження критеріїв, що забезпечують конкурентні переваги підприємства (Nitsenko et al., 2018), концепцій оцінки рівня конкурентоспроможності підприємства і продукції (Senyshyn et al., 2020). Значна увага звертається на розробку стратегі забезпечення конкурентних переваг (Haidai et al., 2020).

Сільське господарство України має високий експортний потенціал. Після набуття членства у СОТ предметом дискусій у наукових виданнях є способи реалізації конкурентних переваг на зовнішньому ринку та можливості щодо реалізації цих переваг (Radzivill et al., 2019), переорієнтації товарної структури експорту для зменшення частки сировини і збільшення обсягів експорту переробленої продукції (Meyers et al., 2018). Через високу ризиковість сільського господарства вивчаються методи оцінки ризиків, способи ї урахування та протидії. Найпоширеніші підходи полягають в обгрунтуванні розширення асор- тименту продукції та диверсифікації виробництва (Riepina et al., 2020).

Реформування сільського господарства України на засадах приватної власності та ринкових відносин здійснювались без обгрунтування прийнятних життездатних організаційно-правових форм господарювання, здатних адаптуватись до ринкового середовища. У даний час аналізуються результати реформ, пропонуються підходи до формування прийнятної інституційної структури (Sirenko et al., 2021). Зростає кількість публікацій з проблем розробки і здійснення прийнятної для суб'єктів господарювання аграрної політики, спрямованої на реалізацію економічного потенціалу різних за розмірами та організаційними формами підприємств (Gridchina et al., 2016; Mushtay \& Shumkova, 2017). Часто пропонуються загальноприйняті у економічно розвинутих країнах підходи до вирішення проблем вітчизняного сільського господарства. Майже не вивчаються проблеми впливу на ринкову поведінку суб'єктів господарювання характеристики рівня сформованості ринку та його інфраструктури, особливостей національного аграрного ринку.

3 урахуванням цього метою статті є вивчення можливостей адаптації сільськогосподарських підприємств до ринкового середовища, обгрунтування способів такої адаптації в умовах існуючого стану аграрного ринку.

\section{Матеріал і методи досліджень}

Дослідження здійснювались 3 використанням загальноприйнятих наукових методів. Монографічний метод використано для виявлення проблем адаптації сільськогосподарських підприємств до ринкового середовища, метод порівняльного аналізу - для вивчення можливостей адаптації до ринку різних за розмірами аграрних підприємств, розрахунковоконструктивний метод - для вивчення волатильності цін і необхідності перепрофілювання підприємства.

\section{Результати та їх обговорення}

Реалізація відомих теоретичних основ адаптації суб'єктів господарювання до ринкового середовища у сільському господарстві ускладнена. Складність визначається як галузевими особливостями, так і рівнем сформованості аграрного ринку та його інфраструктури. Ринок сільськогосподарської продукції за організаційною побудовою близький до мікроекономічної 
моделі ринку чистої конкуренції. Не маючи можливості впливати на ціну продукції, зусилля суб'єкта господарювання спрямовуються на пристосування до існуючого рівня та співвідношення цін. У сільському господарстві така адаптація ускладнюється тривалим виробничим періодом і проблемністю прогнозування цін у такому періоді. При цьому через неналежну сформованість ринкової інфраструктури вітчизняний аграрний ринок не виконує характерної для ринку чистої конкуренції функції стабілізації цін. Майже не функціонують аграрні біржі і не здійснюються біржові торги. Не здійснюються аукційні торги на оптових ринках сільськогосподарської продукції. Через високий рівень монополізації сфери закупівель сільськогосподарської продукції ціни не генеруються ринком, а формуються під монопольним впливом окремих закупівельних організацій. Поєднання впливу об'єктивних чинників кон'юнктури ринку та монопольних тенденцій у ціноутворенні призводить до високої волатильності цін, адаптуватись до якої неможливо ні у довготерміновому, ні у короткотерміновому ринковому періоді. Наприклад, закупівельні ціни на живу масу тварин, реалізовану сільськогосподарськими підприємствами України у 2017 році на 40 \% були вищими порівняно з цінами 2016 року, а у 2019 році на 2,2 \% нижчими порівняно з цінами 2018 року. За умови, що ціни не забезпечують навіть середнього у галузі рівня прибутку на капітал, ресурси підприємства використовуються для виробництва альтернативних видів продукції, а за умови забезпечення вищої, ніж у інших галузях прибутковості - ресурси використовуються на користь виробництва даного товару. Для адаптації підприємства до існуючого у 2017 році рівня цін слід було купувати засоби, необхідні для вирощування худоби на м'ясо, а після 2018 року демонтувати і продавати ці засоби. Більшість засобів виробництва у сільському господарстві можуть використовуватись лише для виробництва окремих видів продукції. Перепрофілювання підприємства 3 метою адаптації до ціни передбачає вилучення одних засобів і придбання інших. Реалізувати вилучені засоби для виробництва економічно непривабливої продукції можна лише за ціною, суттєво нижчою від залишкової вартості засобу. Через невизначеність очікуваного рівня ціни на продукцію і високу ризиковість, як правило, не оформляються банківські кредити для придбання засобів, необхідних для виробництва альтернативної продукції.

Проблема посилюється тим, що в Україні відсутні служби, що здійснюють прогнозування цін, а кадрове забезпечення і фінансові можливості окремих, навіть порівняно великих підприємств недостатні для розробки таких прогнозів. При цьому тривале реформування сільського господарства на ринкових засадах поєднується $з$ відсутністю у фахівців та власників сільськогосподарських підприємств досвіду маркетингових досліджень. Окремі маркетингові функції переважно виконують випадкові працівники. Розробку цінової політики та заходів з адаптації до існуючих цін здійснюють, як правило, головні бухгалтери. Вирішуються оперативні поточні завдання без стратегічних підходів щодо позиціювання і забезпечення конкурентних переваг підприємства на окремих цільових ринках. Не визначаються цілі розвитку підприємств відповідно до їх можливостей. На досягнення цих цілей не зосереджуються обмежені ресурси.

Пріоритетно розвиваються особливо великі за розмірами сільськогосподарські підприємства холдингового типу, діяльність яких спрямована на зовнішні ринки, де ціни стабільніші. При цьому часто абсолютизуються переваги великих виробництв. Такі переваги забезпечуються ефектом масштабу. Технологічні процеси у великих виробництвах більш механізовані. Тут використовуються продуктивніші та ефективніші технічні засоби. Цим досягається вища продуктивність праці працівників, які обслуговують такі засоби. За рахунок великих обсягів виробництва продукції знижується іiі капіталомісткість. По мірі збільшення розмірів товарних партій зростає ефективність транспортних та навантажувально-розвантажувальних операцій. До роботи у великих підприємствах залучаються вузькопрофільні фахівці. Цим забезпечується належне виконання усіх технологічних операцій, зростає їх ефективність та ефективність функціонування підприємства загалом. Все ж пріоритетність розвитку великих суб'єктів господарювання аграрного профілю в Україні $є$ результатом використання значних площ родючих земель, реалізації можливостей виробництва дешевої сировини і виведення іiі на зовнішні ринки в умовах активізації міжнародних інтеграційних процесів. Конкурентні переваги досягаються низькою собівартістю продукції завдяки синергетичному результату від поєднання ефекту масштабу та залучення родючих земель.

Зростання експортного потенціалу сільського господарства та збільшення обсягів валютних надходжень є позитивним результатом такого підходу до адаптації суб'єктів господарювання до ринкового середовища. Однак такий результат поєднується 3 сировинною орієнтацією сільського господарства, зростанням безробіття у сільських населених пунктах, посиленням у них економічних та соціальних проблем. Крім того вагомим недоліком такого підходу до реалізації ринкових можливостей суб'єктів господарювання $\epsilon$ проблемність швидкого реагування на зміни у кон'юнктурі ринку. Порівняно 3 невеликим підприємством перепрофілювання великого займає більше часу. По мірі посилення конкуренції на ринку і турбулентності ринкових процесів зростає значимість даних чинників. На висококонкурентних ринках зростає диференціація споживачів за вимогами до продовольчих товарів. Через це в економічно розвинутих країнах втрачають конкурентні позиції великі супермаркети, у яких пропонується недиференційована продукція масового виробництва 3 використанням інтенсивних технологій. Зростає популярність невеликих партій продукції місцевих виробників, яка за ознаками прийнятна для потенційних споживачів цільових сегментів ринку. Ринковий успіх в таких умовах можливий на основі сегментації ринку, виявлення привабливих для підприємства сегментів і фокусуванні зусиль на даних сегментах.

Для виведення на ринок прийнятної для споживача продукції необхідна узгоджена діяльність усіх 
суб'єктів господарювання, які займаються виробництвом сировини, ії переробкою та дистрибуцією продукції на цільовому сегменті ринку. Це досягається структуризацією ринку, формуванням груп підприємств, розташованих географічно близько та функціонально пов'язаних. Існують різні організаційні форми таких об'єднань. Історично першими в умовах економічної кризи в кінці XIX століття були кооперативні об'єднання, які створювались невеликими сільськогосподарськими виробниками для спільної переробки та дистрибуції продукції. Створені у цей час кооперативи до цього часу функціонують у переважній більшості економічно розвинутих країн. Завдяки кооперативам вдається долати монопольні тенденції у сфері закупівель продукції та ціноутворення на неї, у значній мірі стабілізувати ціни. Чисельні рекомендації щодо створення таких кооперативів в Україні, організаційні зусилля органів управління сільським господарством та пряма державна фінансова підтримка забезпечили створення кооперативів, які функціонують переважно формально. У поширених рекомендаціях пропонується створювати кооперативи для спільної заготівлі продукції і її постачання на існуючі переробні підприємства. Переваги таких кооперативів полягають лише у забезпечені підвищення ефективності логістичних операцій у процесі заготівель продукції та іiї постачання на переробку. Такі кооперативи не мають впливу на ціну. Продукція поставляється кооперативами на переробні підприємства за тими цінами, за якими вона поставлялась би кожним сільськогосподарським виробником і без створення кооперативу. Ще одна принципова відмінність вітчизняних кооперативних формувань від тих, що поширені у економічно розвинутих країнах полягає в тому, що тут не здійснюється погодження вимог до сировини 3 урахуванням ознак кінцевих продуктів переробки, які забезпечують конкурентні переваги на цільових сегментах ринку. Упущення з поля зору ключових підходів до створених кооперативів, що забезпечують адаптацію до ринку і конкурентні переваги засновників та учасників $\epsilon$ основною причиною їх формального функціонування.

Альтернативними для виробництва конкурентоспроможної на окремих сегментах ринку продукції $є$ господарські структури, що створюються переробними підприємствами. Переробні підприємства організовують і здійснюють виробництво сільськогосподарської сировини, придатної для виробництва кінцевої продукції відповідно до вимог споживачів. У таких структурах може вироблятись продукція, конкурентоспроможна і на зовнішніх ринках. На відміну від експорту сировини цим досягається створення більшої доданої вартості продукції, додаткових робочих місць, надходження коштів до державного бюджету, належне використання можливостей, що створюються активізацією міжнародних інтеграційних процесів в Україні. Набуває популярності крафтова продукція. Вона пропонується невеликими підприємствами, у яких поєднуються усі операції з виробництва та переробки сільськогосподарської продукції. Може пропонуватись продукція, вироблена за індивідуальними замовленнями окремих споживачів. Вища собівар- тість такої продукції, порівняно із собівартістю продукції, виробленої на великих підприємствах тут компенсується вищими цінами і забезпечується такий же прибуток на капітал, як і в умовах масового виробництва.

Реалізація ринкових можливостей невеликих сільськогосподарських підприємств стримується неналежною інфраструктурою аграрного ринку. Невеликі виробники мають обмежені можливості щодо пошуку i вибору прийнятних для них каналів розподілу. Супермаркети віддають переваги великим виробникам сертифікованої продукції, які здійснюють поставки необхідних обсягів такої продукції. Часто віддається перевага імпортній продукції, навіть цій, виробництво якої районоване в Україні. Така продукція відкалібрована, пропонується під відомими брендами.

Міські продовольчі ринки та оптові ринки сільськогосподарської продукції більше прийнятні для суб'єктів господарювання, що здійснюють комерційну діяльність на постійній основі, ніж для виробників сільськогосподарської продукції. Це у значній мірі стримує підприємницьку діяльність у селах, трансформацію особистих селянських господарств у фермерські господарства товарного типу. Не забезпечує очікуваних результатів пряма державна підтримка фермерських господарств та спрощення процедури їх створення без реєстрації як юридичної особи.

Без сформованого аграрного ринку пряма державна фінансова підтримка має лише компенсаційний характер. Вона частково ослаблює проблему забезпечення прибуткового функціонування. При цьому вагоміший вплив на фінансові результати має цінова нестабільність, ніж державна фінансова підтримка.

\section{Висновки}

Проблеми адаптації вітчизняних сільськогосподарських підприємств до ринкового середовища складні і багатопланові. Вони визначаються як загальними особливостями сільського господарства, так і специфічними, характерними лише для вітчизняних суб'єктів господарювання проблемами неналежної сформованості аграрного ринку та його інфраструктури.

Вітчизняний ринок сільськогосподарської продукції не виконує функцій стабілізації цін. В умовах високої мінливості цін не здійснює належного стимулюючого впливу державна фінансова підтримка виробників сільськогосподарської продукції.

Основними напрямами державного сприяння адаптації сільськогосподарських підприємств до ринкового середовища і їх ефективному та сталому функціонуванню $є$ формування ринкового середовища; розбудова інфраструктури аграрного ринку; дослідження i прогнозування ринкової кон'юнктури, доведення інформації щодо цього до суб'єктів господарювання; створення і підтримка саморегулівних об'єднань, у яких формувались би прийнятні для їх учасників ціни на продукцію, погоджувались вимоги до сировини тощо. 


\section{References}

Czyzewski, B., \& Majchrzak, A. (2018). Market versus agriculture in Poland - macroeconomic relations of incomes, prices and productivity in terms of the sustainable development paradigm. Technological and economic development of economy, 24(2), 318-334. doi: 10.3846/20294913.2016.1212743.

Gridchina, A., Orekhova, L., Lyubimtseva, S., Yakovenko, N., \& Komov, I. (2016). Agrarian policy of the region in terms of economic development innovation. International Journal of Economics and Financial Issues, 6(S8), 54-59. URL: https://www.econjournals.com/index.php/ijefi/article/ view/3699/pdf.

Haidai, O., Bahorka, M., Satyr, L. Bondarchuk, N., \& Yurchenko, N. (2020). Complex procedure for implementation of the strategy of competitiveness ensuring of Ukraine's agrarian sector. Management Theory and Studies for Rural Business and Infrastructure Development, 41(4), 537-546. doi: $10.15544 / \mathrm{mts} .2019 .44$.

Meyers, W., Karasova, N., \& Yatsenko, O. (2018). Highly marginal goods as source of export efficiency rise in agrarian sector. Management Theory and Studies for Rural Business and Infrastructure Development, 40(4), 577-586. doi:10.15544/mts.2018.50.

Mushtay, V., \& Shumkova, O. (2017). Etermination of potential opportunities for the food provision with grain production: a Ukrainian and European viewpoint. Baltic journal of economic studies, 3(5), 334-342. doi:10.30525/2256-0742/2017-3-5-334-342.

Nitsenko, V., Mardani, A., Kuksa, I., \& Sudarkina, L. (2018). Additional opportunities for the systematization of the marketing research for resource conservation practice. Management Theory and Studies for Rural Business and Infrastructure Development, 40(3), 361368. doi: 10.15544/mts.2018.34.
Pauhofova, I., \& Qineti, A. (2002). The basic determinants of price development in agriculture and food industry of Slovakia. Ekonomicky casopis, 50(2), 165-181. URL: https://www.researchgate.net/publication/287664427.

Radzivill, O., Minka, T., Sereda, Y., Strelchenko, O. \& Yuriy, P. (2019). Prospects and challenges for the Ukrainian agricultural market under the association agreement with the European Union: legal analysis. Management Theory and Studies for Rural Business and Infrastructure Development, 41(2), 153-167. doi: $10.15544 / \mathrm{mts} .2019 .14$.

Rembisz, W., \& Waszkowski, A. (2018). Price relationships of the production factors as exogenous determinants of production in agriculture. Common agricultural policy of the European Union - the present and the future: EU member states point of view, 81-92. doi: 10.30858/pw/9788376587431.7.

Riepina, I., Chukhraieva, N., \& Kehrein, E. (2020). The influence of market risks upon the agribusiness value. Management Theory and Studies for Rural Business and Infrastructure Development, 42(1), 35-40. doi: $10.15544 / \mathrm{mts} .2020 .04$.

Senyshyn, O., Kundytskyj, O., \& Zlydnyk, M. (2020). Concept of product competitiveness management system and principal scientific approaches to its understanding. Management Theory and Studies for Rural Business and Infrastructure Development, 42(2), 157-170. doi: 10.15544/mts.2020.16.

Shyian, N., Moskalenko, V., Shabinskyi, O., \& Pechko, V. (2021). Milk price modeling and forecasting. Agricultural and Resource Economics: International Scientific EJournal, 7(1), 81-95. doi: 10.51599/are.2021.07.01.05.

Sirenko, N., Baryshevska, I., \& Melnik, O. (2021). Theoretical aspects of institutional support for the development of agricultural enterprises. Management Theory and Studies for Rural Business and Infrastructure Development, 42(4), 452-457. doi: $10.15544 / \mathrm{mts} .2020 .46$. 